\title{
Social Justice Pre-Practicum: Enhancing Social Justice Identity Through Experiential Learning
}

\author{
Samuel Sanabria \\ Leigh DeLorenzi \\ Rollins College
}

\begin{abstract}
The counseling profession calls counselors to engage in social justice advocacy and charges counselor education programs to prepare students for this work. While most counseling programs promote social justice knowledge through a single course and infusion model, there remains a standard practice in providing students with experiential opportunities in advocacy to improve their learning. A qualitative study used a focus group methodology to examine the effectiveness of a social justice pre-practicum in the development of a social justice identity with counseling students. The study examines whether participation in a social justice prepracticum reinforces a personal connection to and a broader understanding of social inequalities and advocacy work, as well as encourages more engagement in systemic advocacy in current employment. The purpose of this article is to encourage counselor education programs to equip students with real-life experiential opportunities in advocacy work by adopting a similar social justice pre-practicum course in their curriculum.
\end{abstract}

Keywords: social justice, counselor education, pre-practicum, training, experiential learning. 
For nearly 30 years, the helping profession has called on counselors to advocate for the change of societal policies, practices, and procedures that perpetuate systemic forces of oppression and marginalization (Vera \& Speight, 2003). After decades of dialogue between those who supported (Arredondo \& Perez, 2003; Greenleaf \& Bryant, 2012; Helms, 2003; Pieterse, Evans, Risner-Butner, Collins, \& Mason, 2009; Smith, Reynolds, \& Rovnak, 2009) and opposed (Hunsaker, 2011; Wreghitt, 2015) social justice advocacy as a core part of the counselor's professional identity and practice, the Council for Accreditation of Counseling and Related Educational Programs (CACREP, 2009, 2016) expanded their standards to include instruction on social justice advocacy within training programs. While the American Counseling Association's (ACA) Code of Ethics (ACA, 2014) also emphasized the need for counselor education training programs to infuse multicultural education throughout the curriculum (F.7.c), direct opportunities for student engagement in advocacy have been often missing (Haskin \& Singh, 2015; Zalaquett, Foley, Tillotson, Dinsmore, \& Hoff, 2008).

The objective of social justice counseling is to, “...facilitate the removal of external and institutional barriers to clients' well-being” (Toporek \& Lui, 2001, p. 387) and advocate for a society in which all individuals can experience full equality, regardless of their identity or social location (Toporek, Gerstein, Fouad, Roysircar, \& Israel, 2006). The primary tenant of the movement posits that mental health professionals have a more significant impact on society by acting as change agents for social institutions than they do by providing mental health services alone (Lopez-Baez, \& Paylo, 2009). When engaging in advocacy on the micro (e.g., individual) level, counselors can encourage clients to find their voice to advocate for themselves. As described in Chung and Bemak's (2011) book on social justice counseling, this involves fostering client empowerment. Micro-level advocacy is an equal partnership between counselor and client as the client gains confidence, take action, and generates change in their surrounding environments. On the meso- and macro- levels, counselors work as social agents at the community, systemic, and sociopolitical levels (Greenleaf \& Bryant, 2012; Lewis, Arnold, House, \& Toporek, 2002). When counselors fail to consider the impact that oppression has on society while stressing the importance of individual determination, they limit the overall impact they can have in promoting well-being for clients and communities (Vera \& Speight, 2003).

Academic activists have traditionally been the main drivers for the current social justice movement (Lopez-Baez, \& Paylo, 2009; Motulsky, Gere, Saleem, \& Trantham, 2014). Perhaps in response to calls from within the counseling profession to infuse social justice principles and training in counselor education programs (Constantine, Hage, Kindaichi, \& Bryant, 2007; Talleyrand, Chung, \& Bemak, 2006), many counselor education programs have included social justice content in their curriculum with some experiential learning advocating on the individual (client) level (Pieterse et al., 2009). However, social justice education has lacked adequate experiential learning opportunities for students to engage at the community and societal level which would offer a broader understanding of the importance of social change and advocacy as well as their professional responsibilities (Dollarhide, Clevenger, Dogan, \& Edwards, 2016; Fawcett, \& Evans, 2013). Moreover, Pieterse and colleagues (2009) noticed that counselor educators place a higher emphasis on awareness and knowledge when it comes to multicultural and social justice counseling, with less focus on the development of associated skills. Because advocating for social justice is mainly an action-oriented skill, a greater emphasis on developing this competency in counselor education programs is necessary.

Constantine et al. (2007) identified nine social justice competencies that can be used to assist counselor educators in their training of students. The first six competencies concentrate on awareness and knowledge, and the last three focus on skills. Constantine and colleagues $(2007$, p. 26) proposed that counselors, “...collaborate with community organizations in democratic partnerships..." and, “...develop system interventions and advocacy skills..." in order to support change at the community and institutional level. They recommended that counselor education programs provide service-learning experiences to students so they can work directly with local agencies engaging in social change work for legal, public policy, and educational institutions. By recognizing 
that counselor advocacy includes more than just acting on the individual level, students can adequately frame clients' problems from a social, political, cultural, and economic perspective.

\section{The Social Justice Pre-Practicum Course}

Our faculty developed a social justice pre-practicum (SJPP) course to satisfy the dual goals of teaching social justice and expanding experiential learning for students. These goals have been reinforced by calls to action given by academic activists and thought leaders on social justice advocacy in graduate programs (Chang, Crethar, Ratts, \& Editors, 2010; Green, McCollum, \& Hays, 2008; Ratts \& Wood, 2011; Vera \& Speight, 2003). At the time of the SJPP's inception in 2011, few systemic-level advocacy-specific experiential learning models existed within counselor training programs (e.g., Bemak \& Chung, 2007; Bemak \& Chung, 2011; Burnes \& Manese, 2008). The purpose of this article is to encourage counselor education programs to provide real-life experiential opportunities in advocacy work by examining the effectiveness of this SJPP course on students' social justice identity development. Social justice identity is defined as having a pervasive internalization of social justice values characterized by 1) a personal connection with advocacy work, 2) a broader understanding of social inequities and advocacy work, and 3) current engagement in systemic advocacy work. The authors will summarize the SJPP course, as well as the perceptions and experiences of a focus group of alumni who participated in this course during their master's program. Furthermore, it is important to note that we consider ourselves a social justice program, and as a department, each faculty member has a personal commitment to social justice. We stand together in our advocacy identity, which is reflected in our teaching, research, community work, and personal lives.

\section{The Course Design}

When teaching students about specific meso- and macro-level social justice advocacy activities in counseling, we refer to the Advocacy Competencies developed by Lewis et al. (2002) and updated by Toporek and Daniels (2018). Endorsed in 2003 by the ACA Governing Council, the advocacy competencies provide a set of guidelines for competent practice. The competencies fall into six domains: (a) client/student empowerment, (b) client/student advocacy, (c) community collaboration, (d) systems advocacy, (e) public information, and (f) social/political advocacy (see Figure 1). This model provides both a practical and conceptual understanding of the advocacy domains that support the development of a social justice identity. In addition to providing regular structured didactic time discussing social justice concepts in the classroom, we believe students develop a deeper personal connection and understanding of social justice theory through active participation in advocacy work that goes beyond classroom teachings and discussions. Our pedagogical philosophy was inspired by seminal experiential models of learning (Dewey, 1938; Kolb, 1984), as well as current approaches to social justice pedagogy (Bemak \& Chung, 2011; Collins, Arthur, Brown, \& Kennedy, 2015; Feather, Bordonada, Nelson,\& Evans, 2019; Green et al., 2008). Experiential models of learning emphasize active participation with real-life experiences followed by reflective observation, while current theories of social justice education underscore the importance of raising social consciousness and promoting social action (Steele, 2008). With these philosophical approaches to learning as the basis for course development, the department labeled the course as a pre-practicum in social justice to signify its placement earlier in the program of study. We estimated that the sooner students begin to synthesize social justice theory into counseling theory, the sooner they would be able to develop their social justice identity. 
Figure 1: Advocacy Competencies

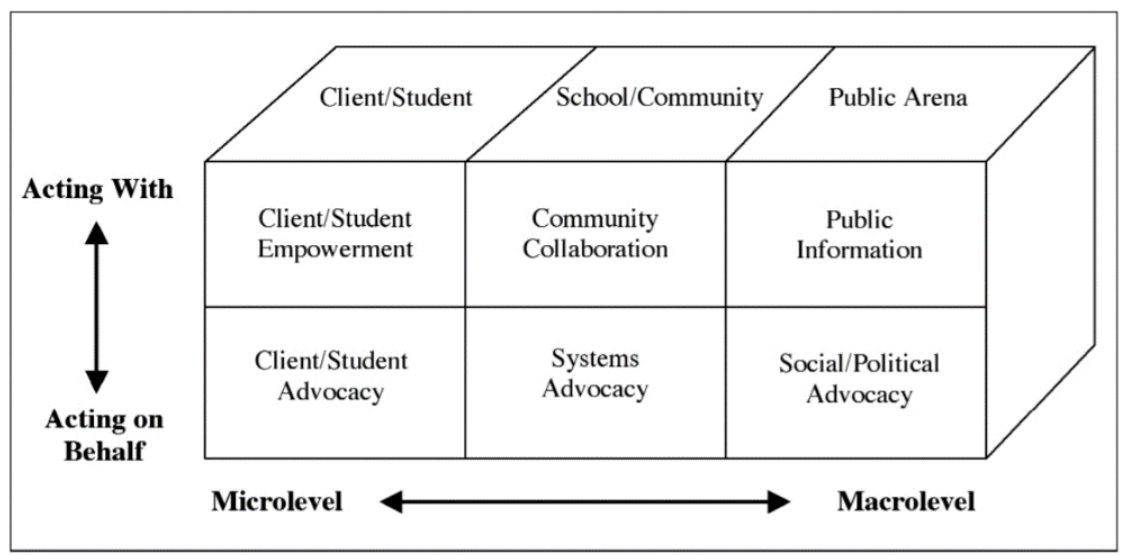

Note. Social Justice Advocacy Domains. Adapted from Lewis, Arnold, House \& Toporek (2002) from https://www.counseling. org/docs/default-source/competencies/aca-advocacy-competencies.pdf?sfvrsn=d177522c 4. Endorsed 2003 by the American Counseling Association. Permission to use figure granted by the American Counseling Association.

SJPP within the program of study. Full-time students enrolled in our program complete all training requirements within three years. Within this lock-step cohort model, students complete all courses in a specific sequence, and each full-time cohort moves through the curriculum at the same pace. Rather than have a stand-alone course that covers concepts associated with social justice counseling, our program sequences and reinforces social justice content starting in each student cohort's first semester. Social justice topics, including the Multicultural and Social Justice Counseling Competencies (Ratts, Singh, Nassar-MCcMillan, Butler \& McCullough, 2015), are heavily emphasized and systematically reinforced within all first-year courses, including Foundations of Mental Health Counseling, Ethics, Counseling Skills, Research, and Assessment. Full-time students complete the SJPP course over the second year of the program of study. Thus, in addition to their traditional second-year coursework, students complete a unique 100-hour service-learning component outlined in detail below.

The 100-hour SJPP requirement fits within the CACREP requirement for 1000 hours of pre-graduate clinical work. CACREP specifies that counselor education programs dedicate 700 of the 1000 hours to both practicum (minimum of 100 hours) and internship (minimum of 600 hours). From the 300 undesignated clinical hours remaining from this 1000 -hour requirement, our program requires students to use 100 hours toward the SJPP requirement. The SJPP course structure and hour designation has been reviewed and approved twice by CACREP during our reaccreditation process.

Pre-practicum site selection. The SJPP course differs from a traditional course format in that it provides students with direct experience advocating alongside historically oppressed groups in the community. First, each student selects a site with which to complete the service-learning component by identifying community organizations that are of personal interest to the student. Our training program created a reference list for students describing local organizations that are engaged in social justice advocacy work on both regional and statewide levels. These local organizations include (but are not limited to) Planned Parenthood, Farmworkers Association of Florida, college Title IX offices, lesbian, gay, bisexual, transgender, and questioning (LGBTQ) housing and support organizations, and service centers for victims of sexual assault. Before students begin their pre-practicum fieldwork, they must be interviewed and selected by their organization of choice.

100 hours of social justice. Once site selections are approved, students embark on 100 hours of volunteer advocacy where they (a) learn about the organization and the population they serve, (b) develop and execute a meso- and macro-level advocacy project, and (c) distill their learning further through written reflection. 
Examples of advocacy projects include meeting with local lawmakers and community leaders, assisting in organization fundraising, writing letters to state legislators, and educating the community on social issues.

Students receive guidance, mentoring, and support at their pre-practicum sites and on campus. They work closely with a staff member as they develop their specific social justice projects and interact with the community as a member of their selected organization. On campus, students communicate regularly with a faculty member who functions as the clinical practice coordinator for all students. This clinical practice coordinator helps students select a site of interest, facilitates the partnership contracts between each student and pre-practicum site, monitors each student's progress, and addresses any concerns as they arise. Students are also able to propose sites to the clinical practice coordinator if they believe there is a community organization that would be a good fit for the requirement. Students are expected to provide their transportation to and from their pre-practicum sites, as they are with clinical sites during practicum and internship. Detailed descriptions of the roles and responsibilities for graduate students, pre-practicum site supervisors, and the faculty clinical practice coordinator can be found in Table 1, as published in our program's Pre-Practicum Guidebook.

\section{Table 1: Pre-Practicum Agreement - Roles and Responsibilities}

\section{Graduate Student agrees to:}

- Behave professionally and ethically at all times by following the ethical guidelines of the American Counseling Association and/or the American Mental Health Counselors Association.

- Abide by the administrative policies, standards, regulations, schedules, and practices of the Pre-practicum Site. Identify himself or herself to the public as a "Graduate Counseling Student."

- Maintain professional liability insurance throughout the pre-practicum.

- Consistent and punctual attendance at all scheduled activities as agreed upon with the Pre-practicum Site Coordinator (a minimum of 5 hours per week for continuous weeks until 100 hours are completed).

- Notify the Pre-practicum Site Coordinator and the Clinical Coordinator in writing of any decisions to discontinue work at the pre-practicum site.

- Fulfill objectives and procedures, as published in the Pre-practicum Guidebook.

- Maintain weekly logs, initialed by the Pre-practicum Site Coordinator, and submit final documentation to the Clinical Coordinator.

- Ensure a valuable learning experience by communicating with the Clinical Coordinator and/or Pre-practicum Site Coordinator as needed or if there are difficulties.

\section{Pre-Practicum Site Coordinator agrees to:}

- Provide opportunities for the Counseling Student to participate in experiential activities appropriate to the definitions listed above.

- Regard the Counseling Student as a professional-in-training and afford her or him the generally expected professional courtesies.

- Verify the Graduate Student's volunteer activities in the documentation provided by the student.

- Complete the final verification of hours form and a brief evaluation of the Graduate Student's contribution to the prepracticum site.

- Notify the Faculty Clinical Coordinator of any concerns about the Graduate Student's performance.

- No party shall discriminate or be discriminated against based on race, color, disability, nationality, ethnicity, age, sex, religion, ancestry, or any other basis prohibited by law.

\section{Faculty Clinical Coordinator agrees to:}

- Facilitate communication between the College and the Agency Site about the counseling student's progress.

- Be available for consultation with both the Pre-practicum Site Coordinator and Counseling Student as needed.

- Require the Counseling Student to purchase student professional liability insurance and will maintain evidence of student liability insurance coverage.

Roles and Responsibilities of Graduate Student, Site Agency, and Faculty Clinical Placement Coordinator (2019) from the PrePracticum Guidebook. 


\section{Effectiveness of Pre-Practicum in Social Justice}

For over 80 years, the literature on effective teaching methods has underscored how experiential learning models can yield a deeper understanding and appreciation for course subject matter than didactic learning methods alone (Bemak \& Chung, 2011; Dewey, 1938; Edwards \& Usher, 1998; Kolb, 1984; Liszka, 2013). In developing an SJPP course, we hypothesized that students would develop a social justice identity as evidenced by 1) a personal connection with advocacy work, 2) a broader understanding of social inequalities and advocacy work, and 3) current engagement in systemic advocacy work. To evaluate our efforts, we conducted a focus group study of alumni to define the peak experiences and challenges of engaging in advocacy work, and how they were integrating what they learned about advocacy in their current work. The final part of the focus group study included an invite to provide suggestions for improvement. The following section summarizes the perceptions and experiences of alumni who participated in the SJPP course.

\section{Method}

The authors received IRB approval to conduct a focus group to learn more about the experiences of alumni who participated in the SJPP course. Faculty researchers were interested in assessing four main areas: (a) peak experiences during the SJPP course, (b) benefits gained from participating in the SJPP course, (c) challenges of participating in social justice work within current employment, and (d) current personal and professional applications of social justice work. An additional question regarding recommended changes to the current structure of the pre-practicum course was also included.

\section{Participants}

Participants were recruited from a database of alumni who participated in the SJPP. Program faculty collaborated to identify students who had graduated since 2011, which was the year of the first graduating class who participated in the pre-practicum in social justice. Selected alumni received an email invitation to participate in a focus group in order to share their experiences and perceptions of the SJPP course for a research study. Members received lunch for their participation. Of the alumni who voiced interest in participating in the focus group, the final sample was narrowed based on alum locale, availability, and current employment as mental health counselors in the community.

The total number of focus groups for this study was one $(n=1)$ with eight participants. Of the participants, six (75\%) were female, and two (25\%) were male. Six (75\%) had a racial identity of White, one (12.5\%) Black and one (12.5\%) Hispanic. The number of years since participants graduated ranged from one to three years, with a mean of 2.5 years $(S D=.89)$ since graduation. Six $(75 \%)$ participants reported employment in various community agencies, and two (25\%) participants reported current employment in private practice. These eight alumni all attended the same focus group.

Participants completed their SJPP experiences at various local organizations dedicated to advocacy work. These organizations included: (a) Equality Florida, a civil rights organization committed to securing equality for the LGBTQ community; (b) Planned Parenthood, an organization dedicated to advocating for the legal and political protection of reproductive rights; (c) Farm Workers Association of Florida, an organization working towards empowering farmworkers and rural poor communities to gain control over the social, political, economic and environmental justice issues that impact their lives; (d) The Center for Inclusion and Campus Involvement, a campus organization focused on creating learning environments that foster students' awareness of self and others; and (e) An Infinite Mind, a non-profit education and community outreach organization dedicated to improving the lives of trauma survivors with Dissociative Identity Disorder. 


\section{The Focus Group}

Faculty did not participate in the focus group discussion but invited an outside facilitator in order to avoid conflicts of interest or any conscious or unconscious influence on participants' responses. The focus group facilitator held a Ph.D. in counseling psychology and was an associate dean for diversity, equity, and inclusion at a university in the southeast region of the United States. The faculty selected the facilitator based on her training and experience with focus groups. The facilitator also had expertise in the practice and teaching of advocacy. Before the focus group, the faculty met with the facilitator to clarify and expand on the purpose of the study and develop discussion questions.

The focus group discussion was video recorded in a conference room on campus. All participants completed an informed consent form. The focus group facilitator began by introducing herself, explaining the purpose of the focus group, and inviting members to introduce themselves. The facilitator then asked questions (e.g., what was a peak social justice experience during your SJPP and How are you engaged in social advocacy in your current place of employment) and systematically allowed every alum to answer every question. Throughout the discussion, she reflected her understanding of the participants' answers, and at times, followed with openended questions to encourage elaboration. The focus group lasted approximately three hours, and participants received breaks, which included time for lunch.

\section{The Analysis}

Researchers employed thematic analysis (TA) to help identify patterns related to lived experiences, opinions, and practices of the participants. TA is a method of systematic procedures for uncovering themes and generating codes from qualitative data (Clark \& Braun, 2017). The researchers followed Braun and Clark's (2006) six phases of TA which are (a) getting familiar with and transcribing the data, (b) generating initial codes, (c) searching for themes, $(\mathrm{d})$ reviewing themes, (e) defining and naming themes, and (f) producing the report. The literature highlights several advantages of using a TA framework for analysis, including the method's potential for generating unanticipated insights, flexibility, and ease of use, accessibility of results to the general public, and engaging participant- collaborator research paradigms (Clarke \& Braun, 2017). Through the systematic TA process, researchers were able to identify trends on the extent to which the SJPP course enhanced social justice identity for alumni, as defined by whether participants expressed: 1) a personal connection with advocacy work, 2) a broader understanding of social inequalities and advocacy work, and 3) current engagement in systemic advocacy work.

An outside company transcribed the focus group video, and one member of the faculty checked the transcripts for accuracy by watching the video while simultaneously reading the transcript. Next, a group of five faculty members participated in the coding of the transcript by hand. All faculty held PhDs in either counselor education or counseling psychology and had previous experience conducting thematic analysis. Additionally, all faculty members participating in the thematic analysis self-identified as having a strong social justice identity as counselor educators. At the time of the thematic analysis, each faculty researcher was engaged in social justice advocacy work through ongoing research, training, writing, and community engagement. Because of this experience and a shared philosophy on the importance of social justice advocacy in training, we believe the TA process was further enriched by the vast expertise of the researchers on these topics.

During the analysis, the faculty read through the transcripts to familiarize themselves with the data. The faculty then reviewed each line of the printed transcription, and coded participant statements as they emerged from the participant narratives. The faculty identified codes at the semantic (i.e., explicit) level (Boyatzis, 1998), meaning the focus was on the content of what each participant said. The coding process moved from organizing patterns of semantic content to the interpretation of broader meanings and implications (Patton, 1990). The process was completed several times for a few statements that were difficult to code, due to differences in 
interpretation of the statement among faculty. However, the faculty was able to reach a consensus on a code for the vast majority of transcribed statements. Two statements were unclear in the video and they were removed from the analysis. The codes were then grouped into identified themes and systematically reviewed, refined and distilled by the faculty. Finally, a summary report was generated by pulling extracts from the transcript and placing them under each corresponding theme which was reviewed again for clarity and accuracy by the research team. The final themes captured the responses of most of the participants. All data was securely stored, and findings are presented anonymously below.

\section{Results}

The authors identified themes that emerged from the participant descriptions. These themes include: (a) peak experiences in the SJPP, (b) perceived benefits of the SJPP course, (c) perceived challenges of social justice work, (d) current applications of social justice work, and (e) recommendations for improvement of the SJPP course.

\section{Peak Experiences During Social Justice Pre-Practicum}

In assessing alumni perceptions of peak experiences in their SJPP work, three themes emerged from the participant responses: (a) feeling empowered, (b) being a witness to social change, and (c) making a difference. These themes support the first hypothesis that graduates would report a personal connection with advocacy work.

Feeling empowered. Participants discussed feeling empowered when working with other advocates for a common cause. Participant A reported that her SJPP experience gave her the courage to speak out on a social and political issue that she felt strongly about, especially after her family socialized her to keep her opinions to herself:

“... I'm going to stand up for what I believe in, and be that voice as much as I have been taught not to be...now I'm not afraid of doing that anymore, so it was definitely helpful, and a good foundation for what I do now."

Being a witness to social change. Participants reported that another peak experience was being a witness to how systematic oppression affects target groups, and how simple acts of advocacy could have a positive impact on people. Participants clarified that course readings on these topics were useful but not as impactful to their learning as observing these phenomena in person. Participant B recalled how she felt inspired by informing same-sex couples that they were able to register as domestic partners after a change in city laws:

"There were so many stories, so many love stories. Some people were excited. Some people were like, 'Oh my God, you can do that?' I'm like, 'Yeah.' 'When?' I'm like, 'You can do it right now. So, it was so exciting just being there for that moment... [seeing] the happiness on their faces, and getting to hear all the stories of love."

Making a difference. Participants also reported that being social justice advocates helped them feel as if they were making a difference in the world and the lives of others. They stated that the feeling of making a difference extended beyond what one would feel by being a support to their clients in therapy. They also expressed feeling that their projects had a lasting impact on agencies after they left. For example, Participant $\mathrm{C}$ worked at the Center for Inclusion and Campus Involvement with economically disadvantaged students. She told the story of working to assist a nontraditional student who was a single mother with financial difficulties and who felt alone in her experience. After helping the student connect with financial resources, the alum created a subcommittee focusing on the unique (and sometimes forgotten) needs of non-traditional students. 
The participant reported that this helped create positive and inclusive experiences for future non-traditional students on campus.

\section{Benefits Gained from Social Justice Pre-Practicum}

Participants reflected on what they gained from their experiences in their SJPP. Two themes emerged from the discussion: (a) confidence, and (b) the power of persistence. These themes support two of the three hypotheses; a personal connection with advocacy work, and a broader understanding of social inequalities and advocacy work.

Confidence. After several participants shared how often they felt uncomfortable with the work during their first exposure to the SJPP, Participant D reflected on how the experience helped her to develop more confidence in speaking up about her beliefs, especially to a large group.

“...we did a women's forum here ... speaking in front of people. It's not really my forte... but [the social

justice pre-practicum] forced me to grow in that area, and to gain confidence."

She then went on to explain how this newfound confidence helped her to continue social justice work at her current employment.

The Power of Persistence. The second theme revealed how persistence in social justice work could lead to social change. Participant B shared how her work helping with the Orange County domestic registration efforts through Equality Florida assisted her to understand the importance of persistence in advocacy work.

"Well, we're going to just keep talking about it... I feel like I have the ability to effect change ... because you just keep at it."

This comment elicited a similar response from Participant E, who stated that, before her SJPP work, she did not see any hope for marriage equality. However, through her work at Equality Florida she realized how vital slow and steady effort could be.

"[I thought] oh, we're never going to get [marriage equality]. Especially not in Florida. And just to see in a few years where we are now is mind-blowing to me. Things seem so overwhelming, but it's just like taking little steps in the right direction... every little voice matters. And look at how we have affected change in just a short amount of time. That's been really empowering."

\section{Challenges Within Current Employment}

Participants were asked to discuss any challenges they experienced in carrying out social justice work within their current employment. Three themes emerged, including (a) working with other professionals who are indifferent to advocacy work, (b) struggling with whether they are pushing too hard, and (c) witnessing how political, social, and economic barriers affect their clients. These themes support the second hypothesis (a broader understanding of social inequalities and advocacy work).

Working with colleagues not trained in social advocacy. Participants discussed the challenges of working with other mental health professionals who may not consider how political, social, and economic barriers affect their clients. Participant A shared her concerns about challenging senior counselors to understand their clients' lived experiences through a social justice lens.

"I would say that my primary challenge that I feel like I experience regularly is when I run into other professionals who don't have the same language, who don't have the same understanding of things. Especially when I feel like I've learned so much here, I want to share that, but I know that will probably just start a debate." 
This observation led Participant F to discuss how the topic of oppression often leads to distracting debates on whether dominant groups encounter oppression in our society. One participant shared an experience in which a male therapist claimed that women in our society oppressed men.

“...when I hear other therapists talking about male oppression...I find it really triggers me, but I don't know what to do with it."

Participant $\mathrm{C}$ talked about working with professionals who do understand the impact oppression has on clients, but have surrendered to systemic barriers within the profession and abandoned hope for change.

"I'm trying to do work with my clients, but then the other professionals that understand the work say, 'It's just a waste of time, it's not worth it.'

Knowing when and how to push. The second theme regarding challenges experienced at current employment included knowing when to advocate and to what extent. Participant F shared what she learned during her time in the counselor education program.

“... something that I did gain through the program is kind of slowing down a hair. I've always been the kind of person who wants to stick it to the man. So, for me, the challenge has been slowing it down."

The participant continued to share an experience she had with an 80-year-old female client who was concerned about her physical appearance after being able to see her wrinkles clearer after eye surgery. The client wanted to explore plastic surgery and other skin rejuvenation treatments.

"She got surgery and could see her face so well that she realized how pronounced the lines were in her face. And it was hard for me. I jumped to, you know, 'How fortunate we are having these wonderful long lives, how great stories are, and who's telling us this is bad?' So, for me, the challenge is like, 'Stop...she's entitled to go get as much Botox as she wants. She's entitled to put on as much makeup as she wants.' So kind of balancing my eagerness is a process for me."

Witnessing how political, social, and economic barriers impact clients. Perhaps the response that elicited the most discussion involved witnessing the impact that political, social, and economic barriers had on clients. Participant F shared her frustrations working at a non-profit agency providing counseling services to economically disadvantaged clients and seeing how difficult it can be for clients to attend their appointments.

“...working at a non-profit, I see a lot of challenges, even with local transportation buses...them getting to their appointments, having bus passes."

She continued sharing how this limitation prevents her from providing needed services.

"So there's a lot of challenges within the environment, and sometimes it's so hard to facilitate that because sometimes the barriers are just so big that you can't get them the services that they need."

Participant G shared her struggles with witnessing how these limitations affect her clients and continued to share how the lack of resources and support prevents her from providing much-needed assistance to her clients.

"They want to improve their lives, but it's almost nearly impossible for them to do so, between all of the different policies related to managed care, and the hoops they have to jump through to get help, that so little of that help actually reaches them. And then on the other side, people trying to go out and find work or find a place to live. They want to pull themselves out of the hole, but they have no means of doing so." 


\section{Current Applications of Social Justice Work}

Participants were asked to describe any current applications of social justice work, and three themes emerged, including (a) strengthening client empathy and case conceptualization, (b) facilitating client empowerment, and (c) educating clients about identity development and oppression. Although participants indicated working with clients on issues of social justice, this approach to advocacy was on the micro-level. Thus, these themes did not support the third hypothesis that students would be engaged in macro-level systemic advocacy work in their practice post-graduation as clinical mental health counselors.

Strengthening empathy and case conceptualization. Participant $\mathrm{H}$ shared how she used her training in social justice work to understand better the varied experiences of her clients, not only from an individual difference perspective but also from a cultural identity perspective.

"I might not be able to completely understand exactly what you're talking about because I haven't lived it, whether that's because you're a man or, you know, Black or Hispanic or whatever... there's so many different factors that go into it that I have to be mindful, and [that can] impact how much I can empathize with somebody."

Participants reported that this process of understanding clients from an ecological perspective enhanced their best care practices. Not only did this experience allow the participant to understand the client's worldview better, but it also allowed her to understand how her privilege or marginalization affected the therapeutic relationship.

Facilitating client empowerment. Participant $\mathrm{G}$ discussed how she used her training in social justice work to include empowerment-based counseling to help female clients better understand their experiences with either privilege or marginalization. The participant shared her experience working with a young female client who was not doing well in school because she felt unsupported and was discouraged from believing that she could be more than a homemaker and mother.

"I just looked into [my client's] eyes, and said, 'You don't have to let people define who you are.' And I think that just really made a point because she was a very resistant client from the beginning."

The participant expressed how rewarding it felt helping the client to develop critical consciousness by encouraging her to understand better her upbringing in the context of her culture and oppressive society. By encouraging this understanding, she was able to help her client unlearn false messages related to privilege and oppression.

Educating clients about identity development and oppression. This question led to a discussion on the different methods for teaching clients the concepts related to identity development and oppression. Participant B shared:

"We have them do... 'How many were you raised in different households? Take one-step forward. The rest stay where you are.' So, we teach them about social justice from that perspective, and on being mindful of the different things."

Participant D shared how she uses Socratic questioning in her self-esteem group to help clients be aware of their privilege and marginalization.

"So, a lot of times we'll talk about [age] and how, for men in particular...balding and how it affects them, and how they're judged differently. Or women and stretch marks... who decided that stretch marks were bad? You know, how things are socially constructed." 


\section{Recommendations for Improvement}

Lastly, the focus group participants shared recommendations for improving the SJPP course. For the most part, participants reported having a positive experience and expressed an appreciation for being in a program with a dedication to social justice education and experience. The recommended improvements included: (a) having in-class discussions about the intense emotions that social justice work can raise, (b) educating students on how to professionally and effectively work with other professionals (i.e., law enforcement), (c) providing students with a list of community resources, and (d) emphasizing how much of community counseling work involves collaborating with other professionals in meeting client's health and human service needs.

Two recommendations stood out as being particularly helpful for improving student experiences. Participant F who completed her SJPP at Farm Workers Association of Florida said she felt disconnected with the population she was advocating for because she was busy working behind the scenes advocating for social awareness.

"[I would have liked to have been] exposed to different groups, different people, hearing about the farmers, and hearing about all the different groups that you all were [working with]. I would have loved to have known more about them."

This comment reinforced what we frequently teach about social justice work, which is having a personal connection with the population in which one serves as an advocate.

The second recommendation from Participant G involved having more opportunities for students to reflect after having actual experiences:

"I think maybe having a process group afterward, and having all the classmates come together to talk about the experiences they took away. I think that would be a wealth of knowledge. Even though you can't live the experience, you can still hear about it."

\section{Discussion}

Advocacy is a crucial aspect of multicultural and social justice competence (Ratts et al., 2015; Steele, 2008). The researchers hypothesized that students engaged in the SJPP course would develop a social justice identity as evidenced by: 1) a personal connection with advocacy work, 2) a broader understanding of social inequalities and advocacy work, and 3) current engagement in systemic advocacy work. The voices of the eight participants in this study provided valuable insight into the effectiveness of implementing an SJPP course in the counselor education curriculum. Several themes emerged that support experiential models of learning (Dewey, 1938; Kolb, 1984) and current approaches to social justice pedagogy (Bemak \& Chung, 2011; Collins et al., 2015; Feather et al., 2019; Green et al., 2008) for enhancing students' personal and professional development. The collective experiences of the participants provided evidence that working with advocacy groups in the community and public arena led to an appreciation for the need for advocacy work, a sense of empowerment and confidence doing advocacy work, and an understanding of how social inequalities and barriers to resources impact target groups. These findings support our first two hypotheses, and also are consistent with existing studies (Bemak \& Chung, 2011; Collins et al., 2015; Feather et al., 2019; Green et al., 2008) on the benefits and challenges of facilitating social justice competencies in graduate education. Similarly, the findings echo previous literature on multicultural pedagogies (Dickson \& Jepsen, 2007; Enns, Sinacore, \& Ancis, 2004) that emphasize how we are teaching over what is taught.

While these results support the main tenants of experiential and social justice pedagogical theories for using real-life experiences to enhance learning, none of the participants exhibited all three characteristics of a social justice identity. Specifically, participants exhibited two of the three critical aspects of a social justice 
identity, including a personal connection to and a broader understanding of social inequalities which reinforces the importance of experiences in learning. However, none of the participants were currently engaged in macrolevel advocacy work in their employment as a clinical mental health counselor.

As may be expected based on experiential (Dewey, 1938; Kolb, 1984) and current approaches to social justice pedagogy (Bemak \& Chung, 2011; Collins et al., 2015; Feather et al., 2019; Green et al., 2008 ), a personal connection to, and a broader understanding of social inequalities and advocacy work was attributed to the SJPP course experience. SPJJ students not only served with organization leaders in coordinating advocacy efforts, but they also came face-to-face with the community impacted the most by social inequalities. The processes of collaboratively working with community leaders and individuals from marginalized communities to advocate for social equality taught students how solidarity and persistence lead to positive differences in these communities. Witnessing even small gains increased student confidence and efficacy, making their experiences more meaningful and personal. Students got valuable exposure on what methods to use for effective community organizing, how to navigate challenging collegial dynamics, how and when to assert pressure on stakeholders, and how to facilitate client empowerment through psychoeducation. Hearing stories of how oppressive social policies, practices, and procedures directly impacted these communities deepened students' understanding of social inequalities and further reinforced for them the need for advocacy work. These are experiences that strengthened not only their social justice identity, but also their overall counselor identity of promoting wellness through social engagement.

However, because participants did not sustain active engagement in systems-level advocacy work after graduation, the third hypothesis was rejected. The researchers suspect that the lack of current advocacy work could be due to the majority of participants being within the first three years of their career post-graduation, and possibly still trying to establish themselves in the field while placing their professional priorities on meeting state licensure requirements. It is also possible that their employers were not supportive or structured for providing opportunities for macro-level advocacy. This finding illuminated for us a possible disparity between our professional expectations and the advocacy opportunities provided by employers.

In order to cultivate active involvement in systems advocacy work, additional educational interventions such as providing specific training on how to promote advocacy opportunities to future employers, may be needed. For example, students might inquire about advocacy opportunities during the job interview or, if already employed, engage in ongoing discussions on the importance of advocacy work with employers and colleagues. Counselor educators can educate students about this disconnect, as well as teach ways to effectively "advocate for advocacy" with employers. We recognize that not all professionals in the helping field share our commitment to social justice and that students may encounter resistance. Therefore, counselor educators can teach students to develop strategies for working more effectively with resistance in order to promote advocacy in their workplace.

An unexpected insight that emerged from the study was the importance of adequately preparing students for the various emotional challenges they may experience doing advocacy work. We knew that multicultural and social justice education could unearth strong feelings, and we made sure to provide adequate in-class opportunities for processing; however, participants reported re-experiencing these feelings during their advocacy work with minimal opportunities to process them. While faculty do discuss the emotional challenges inherent in advocacy work, this finding highlights the need for us to revisit whether we are doing enough to prepare students emotionally.

Participants also highlighted a desire to have a personal connection with the population for which they were advocating. This acknowledgment is an important consideration, and one we neglected to recognize when we first discussed developing the SJPP course. Providing students the choice of social justice organizations with which to partner does not guarantee they will have a personal connection with the specific target population. 
Therefore, helping students develop this awareness before their social-justice partnership may result in more meaningful site selections, rather than assuming that all students will find meaningful work from at least one of the community organizations in our region. Students may also experience more intrinsic rewards with engaging in advocacy work if they feel more connected with the population.

One of the most significant insights from this study was the importance of having opportunities for students to reflect on their experiences with their peers after the completion of their 100-hour SJPP. In developing the SJPP course, we recognized the value of learning through reflection. This reflection process is a critical part of Kolb's (1984) experiential model of learning and a significant part of our approach to counselor education. Perhaps there was an assumption made that students were adequately prepared to enter their SJPP and consolidate their learning through written reflections after completing a year of social justice infused coursework. A more immediate and meaningful opportunity for trainees to process their SJPP experience with each other was necessary.

\section{Further Considerations}

There were several observations made by program faculty over the years since incorporating the SJPP course that was not reflected in the study. For example, one of the main issues that came up as students prepared for their SJPP course was difficulty differentiating volunteer service from social justice work at the meso- and macro- level. Early on, we found ourselves having to explain to students what these differences were as they began to inquire about doing non-social justice volunteerism, like helping to build homes through Habitat for Humanity or providing mental health counseling services specifically for target populations. Even after learning about social justice work in various classes, students were unclear precisely what would constitute systems and community-based advocacy work. This confusion motivated us to begin having this discussion earlier in the program and to address specifically the difference between client service volunteerism and advocacy work for marginalized populations.

In the beginning, we had experiences where the line between valuable advocacy work and essential administrative work was not clear. There were some reports of students working directly with the served population (i.e., escorting women through protesters at a Planned Parenthood clinic) in ways that appeared to be client-centered support rather than social advocacy. This required meeting with the sites to clarify our expectation that students would be engaged in work (i.e., community education, lobbying, organizing rallies) that actively promotes awareness of social inequalities and supports social change. Fortunately, for the most part, one meeting with the site was enough to clarify any misunderstandings. These incidences underscore the importance of maintaining clear communication with students and with sites to reduce any uncertainty regarding direct advocacy experience.

One of the unexpected challenges of creating the pre-practicum in social justice was identifying advocacy groups in the community who would be able to help train our students. We have struggled with increasing the number of social justice sites beyond a small number. In the beginning, our students were limited to working within four distinct advocacy organizations. Some students have suggested organizations based on their interests in specific populations, but many did not meet the strict placement requirements. It is essential that before exploring the option of including advocacy experiences that counselor education programs identify community advocacy organizations that can accommodate students.

Another challenge we faced was providing students with opportunities to connect personally with the population with which they were advocating. This request posed some difficulties, including finding time within an already demanding curriculum to connect students with the population and coordinating with the advocacy group to provide these opportunities.

Finally, in order to accommodate the observations, recommendations, and learnings from this study, we realized a need for a full-time coordinator position. As a result, we requested from our administration an 
increase in the clinical coordinator's position from part-time to full-time status. Once approved, the clinical coordinator developed a half-day debriefing workshop for our students to integrate a few of the participants' recommendations. During these workshops, students discuss their experiences and learning with each other. Although the requirements for the SJPP included a written reflection of their experiences, it was not as impactful as the group reflections that came with the debriefing workshop. Also, with a full-time position, the clinical coordinator was able to periodically check-in with students during their SJPP experience and provide support if needed.

\section{Limitations}

We recognize that counselor education programs are diverse in their structure, locations, and support and that incorporating an SJPP course in the curriculum could yield other challenges. One of the unique features of our program is the relatively small size of our faculty and student population. Having a fulltime clinical coordinator with faculty support was sufficient in developing and managing a pre-practicum in social justice for our students. We were fortunate to have a supportive administration that was familiar with our program and work within the community. We suspect that different challenges would arise with diverse counselor education programs. For example, larger programs may require more than a full-time clinical coordinator to manage successfully the addition of a SJPP course while programs in more rural communities may have limited access to advocacy organizations.

Although social justice training has been a fundamental part of our curriculum, we acknowledge that there are faculty who oppose this learning as a core requirement, which could further complicate the inclusion of an SJPP course. Our intention for presenting this study is to encourage counselor education programs to include more opportunities for experiential learning, whether through a pre-practicum in social justice or other methods and to continue the dialogue on how we can advance our call to action.

Another limitation was the use of a single focus group. Whereas sampling guidelines for quantitative designs require researchers to calculate sample size before a study begins, focus-group sampling is an iterative process. This distinction means focus group researchers should go through the recruit - interview - analyze cycle with different categories of informants until data saturation is reached (i.e., no further themes emerge) (Carlson \& Glenton, 2011; Glaser \& Strauss, 2017; Strauss \& Corbin, 1990). However, Morgan (1997) observed that having too many focus groups is equally problematic and may not result in meaningful or new insights. Therefore, running between three and five focus groups is a good rule of thumb for achieving data saturation (Morgan, 1997). Therefore, using additional focus groups in future research would strengthen the results.

\section{Conclusion}

Based on Dewey's (1938) and Kolb's (1984) theory that experiential training opportunities enhance learning, the researchers set out to examine whether a pre-practicum in social justice would enhance the learning and development of students' social justice identity, which is characterized by (a) a personal connection with advocacy work, (b) broader understanding of social inequalities and advocacy work, and (c) current engagement in systems advocacy. Participants in this study reported several benefits of the social justice pre-practicum, including more confidence and persistence for doing social justice work, as well as strengthened empathy and case conceptualization skills. They cited several challenges, including working with colleagues who lacked sufficient knowledge or understanding of the importance of social justice work, moments of not knowing when or how to engage in advocacy, and emotional exhaustion associated with witnessing the impact of political, social, and economic barriers on clients. Several recommendations for improvement emerged, including having more opportunities to reflect on the pre-practicum experience both in and out of the classroom and training 
students on how to promote advocacy work at their place of employment. Further analysis of the structure of the pre-practicum in social justice is needed in order to address the lack of engagement in advocacy postgraduation further.

The counseling profession has a demonstrated history of commitment to social justice, activism, and advocacy, and we must continue to expand on this commitment by effectively training up-and-coming counseling professionals. Counselor education programs also must continue to advance the social justice movement to help future counselors address the social inequalities that lead to emotional, psychological, and physical discord. Providing opportunities for students to convert their academic knowledge into real-world applications can be accomplished in a variety of creative ways within immediate or more substantial communities.

\section{Corresponding Author}

For correspondence regarding this article, please contact Samuel Sanabria, 1000 Holt Ave -2726, Winter Park, FL, 32789 Emailssanabria@rollins.edu 


\section{References}

American Counseling Association. (2014). ACA code of ethics. Alexandria, VA: Author.

Arredondo, P. \& Perez, P. (2003). Expanding multicultural competence through social justice leadership. The Counseling Psychologist, 31, 282-289.

Bemak, F., \& Chung, R. C.-Y. (2007). Training counselors in social justice. In C. C. Lee (Ed.), Counseling for social justice (2nd ed., pp. 238- 258). Alexandria, VA: American Counseling Association.

Bemak, F., \& Chung, R. C.-Y. (2011). Applications in social justice counselor training: Classrooms without walls. Journal of Humanistic Counseling, 50, 204- 219.

Boyatzis, R. E. (1998). Transforming qualitative information: Thematic analysis and code development. Thousand Oaks, CA: Sage.

Burnes, T. R., \& Manese, J. E. ( 2008). Social justice in an accredited internship in professional psychology: Answering the call. Training and Education in Professional Psychology, 2, 176- 181.

Carlsen, B., \& Glenton, C. (2011). What about N? A methodological study of sample-size reporting in focus group studies. BMC Medical Research Methodology, 11, 26.

Chang, C. Y., Crethar, H. C., Ratts, M. J., \& Editors, G. (2010). Social justice: A national imperative for counselor education and supervision. Counselor Education and Supervision, 50(2), 82-87.

Chung, R. C. -Y., \& Bemak, F. P. (2011). Social justice counseling: The next steps beyond multiculturalism. Thousand Oaks, CA : Sage..

Clarke, V., \& Braun, V. (2017). Thematic analysis. The Journal of Positive Psychology, 12(3), 297-298.

Collins, S., Arthur, N., Brown, C., \& Kennedy, B. (2015). Student perspectives: Graduate education facilitation of multicultural counseling and social justice competency. Training and Education in Professional Psychology, 9(2), 153-160.

Constantine, M., Hage, S., Kindaichi, M., \& Bryant, R. (2007). Social justice and multicultural issues: Implications for the practice and training of counselors and counseling psychologists. Journal of Counseling \& Development, 85, 24-29. doi:10.1002/j.1556-6678.2007.tb00440.x

Council for Accreditation of Counseling and Related Educational Programs. (2009). 2009 standards for accreditation. Alexandria, VA: Author.

Council for Accreditation of Counseling and Related Educational Programs. (2015). CACREP 2016 Standards. Alexandria, VA: Author.

Dewey, J. (1938). Experience and education: Experience as the source of learning and development. Touchstone, NY.

Dickson, G., \& Jepsen, D.A. (2007). Multicultural training experiences as predictors of multicultural competencies: Students' perspectives. Counselor Education and Supervision, 47, 76-95.

Dollarhide, C. T., Clevenger, A., Dogan, S., \& Edwards, K. (2016). Social justice identity: A phenomenological study. Journal of Humanistic Psychology, 56, 624-645. doi:10.1177/0022167816653639

Edwards, R., \& Usher, R. (1998). "Moving” experiences: Globalization, pedagogy and experiential learning. Studies in Continuing Education, 20(2), 159-174.

Enns, C., Sinacore, A. L., \& Ancis, J. R. (2004). Toward integrating feminist and multicultural pedagogies. Journal of Multicultural Counseling and Development, 32, $414-427$.

Fawcett, M. L., \& Evans, K. M. (2013). Experiential approach for developing multicultural counseling competence. Thousand Oaks, CA: Sage.

Feather, K. A., Bordonada, T. M., \& Nelson, K. A. (2019). Social justice advocacy training: An innovative certificate program for counselor education. Teaching and Supervision in Counseling, 1(2), 67-84. 
Glaser, B. G., \& Strauss, A. L. (2017). Discovery of grounded theory: Strategies for qualitative research. New York: Routledge.

Green, E. J., McCollum, V. C., \& Hays, D. G. (2008). Teaching advocacy counseling: A social justice paradigm of awareness, knowledge, and skills. Journal for Social Action in Counseling and Psychology 1(2), 14-29.

Greenleaf, A. T., \& Bryant, R. M. (2012). Perpetuating oppression: Does the current counseling discourse neutralize social action? Journal for Social Action in Counseling and Psychology, 4(1), 18-29.

Haskins, N. H., \& Singh, A. (2015). Critical race theory and counselor education pedagogy: Creating equitable training. Counselor Education and Supervision, 54, 288-301.

Helms, J.E. (2003). A pragmatic view of social justice. The Counseling Psychologist, 31, 305-313.

Hunsaker, R. J. (2011). Counseling and social justice. Academic Quest, 24, 319-340.

Kolb, D.A. (1984). Experiential learning: Experience as the source of learning and development. Prentice Hall, Inc., NJ.

Lewis, J. A., Arnold, M. S., House, R., \& Toporek, R. L. (2002). ACA advocacy competencies. http://www. counseling.org/Resources/Competencies/Advocacy Competencies.pdf.

Liska, J. (2013). Charles pierce's rhetoric and pedagogy of active learning. Educational Philosophy and Theory, 45(7), 781-788.

Lopez-Baez, S. I., \& Paylo, M. J. (2009). Social justice advocacy: Community collaboration and systems advocacy. Journal of Counseling \& Development, 87, 276-283. doi:10.1002/j.1556-6678.2009. tb00107.x

Morgan, D. L. (1997). Qualitative Research Methods: Focus groups as qualitative research. Thousand Oaks, CA: SAGE. doi: 10.4135/9781412984287

Motulsky, S. L., Gere, S. H., Saleem, R., \& Trantham, S. M. (2014). Teaching social justice in counseling psychology. The Counseling Psychologist, 42, 1058-1083. doi:10.1177/0011000014553855

Patton, M. Q. (1990). Qualitative evaluation and research methods (2nd ed.). Newbury Park, CA: Thousand Oaks, CA: Sage.

Pieterse, A., Evans, S., Risner-Butner, A., Collins, N., \& Mason, L. (2009). Multicultural competence and social justice training in counseling psychology and counselor education. The Counseling Psychologist, 37, 93-115.

Ratts, M. J., Singh, A. A., Nassar-McMillan, S., Butler, S. K., \& McCullough, J. F. (2015). Multicultural and social justice counseling competencies. Retrieved from https://www.counseling.org/ docs/default-source/ competencies/multicultural-and-social-justice-counseling-competencies.pdf?sfvrsn=20

Ratts, M. J., \& Wood, C. (2011). The fierce urgency of now: Diffusion of innovation as a mechanism to integrate social justice into counselor education. Counselor Education and Supervision, 50(3), 207-223.

Rollins College. (2017). Rollins evening graduate catalogue. Retrieved from https://www.rollins.edu/evening/ documents/catalogs/GraduateCatalog.pdf

Steele, J. M. (2008). Preparing counselors to advocate for social justice: A liberation model. Counselor Education \& Supervision, 48(2), 74-85.

Smith, S. D., Reynolds, C.A., \& Rovnak, A. (2009). A critical analysis of the social advocacy movement in counseling. Journal of Counseling and Development, 87, 483-491.

Strauss, A. C., \& Corbin, J. (1990). Basics of qualitative research: Grounded theory procedures and techniques. Newbury Park. Ca.: Sage. 
Talleyrand, R. M., Chung, C. C., \& Bemak, F. (2006). Incorporating social justice in counselor training programs: A case example. In R. L. Toporek, L. H. Gerstein, N. A. Fouad, G. Roysircar, \& T. Israel (Eds.), Handbook for social justice in counseling psychology: Leadership, vision, and action (pp. 44-58). Thousand Oaks, CA: Sage.

Toporek, R. L. \& Daniels, J. (2018). ACA advocacy competencies. http://www.counseling.org/Resources/ Competencies/Advocacy Competencies.pdf.

Toporek, R. L., Gerstein, L. H., Fouad, N. A., Roysircar, G., \& Israel, T. (Eds.) (2006). Handbook for social justice in counseling psychology: Leadership, vision, and action. Thousand Oaks, CA: Sage.

Toporek, R.L., \& Liu, W.M. (2001). Advocacy in counseling: Addressing race, class, and gender oppression. In D.B. Pope-Davis \& H.L.K. Coleman (Eds.), Intersection of race, class, and gender in multicultural counseling. (pp. 285-413). Thousand Oak, CA. Sage.

Vera, E.M., Speight, S.L. (2003). Multicultural competence, social justice, and counseling psychology: Expanding our roles. The Counseling Psychologist, 31, 253-272.

Wreghitt, K. (2015). Another perspective on social justice in the counseling perspective. Retrieved from https:// community.counseling.org/blogs/kevin-wreghitt/2015/03/19/another-perspective-on-social-justice-inthe-counseling-profession

Zalaquett, C. P., Foley, P. F., Tillotson, K., Dinsmore, J. A., \& Hof, D. (2008). Multicultural and social justice training for counselor education programs and colleges of education: Rewards and challenges. Journal of Counseling \& Development, 86, 323-329. 